\title{
Effect of season on milk production in Murrah Buffaloes: THI a proven marker
}

\author{
S. K. I. Vasantha ${ }^{1 *}$, Ch. Srinivasa Prasad ${ }^{1}$, B. Rambabu Naik ${ }^{2}$, K. Aswani Kumar ${ }^{3}$, \\ Ch. Venkata Seshaiah ${ }^{4}$ and J. Nikhil Kumar Tej ${ }^{1}$ \\ ${ }^{1}$ Department of Physiology, NTR College of Veterinary Science, Gannavaram, India \\ ${ }^{2}$ Department of Physiology, College of Veterinary Science, Tirupati, India \\ ${ }^{3}$ Department of Biochemistry, NTR College of Veterinary Science, Gannavaram, India \\ ${ }^{4}$ LFC, Gannavaram, India \\ *Corresponding author
}

\section{A B S T R A C T}

Thermal stress is of concern for all livestock production systems and its effects have been studied because of the negative impact on production, health and even mortality. Exposure to high ambient temperature is the major constraint

Keywords

Buffaloes; THI; environmental stress; season and milk production

Article Info

Accepted:

12 March 2021

Available Online:

10 April 2021 on buffalo productivity in hot climatic areas. Hence, the milk productivity is focused in the present study to relate animal stress with productivity of buffaloes. Eight adult female Murrah buffaloes of almost same age and parity were selected in summer and winter season. Metereological variables such as ambient temperature, relative humidity and THI were calculated in summer and winter season. Simultaneously milk production was also recorded in both the seasons. There was a significant increase $(\mathrm{p}<0.05)$ in temperature, humidity and THI in summer compared to winter. From the present study it was concluded that THI is a proven marker that increases during summer and imposed thermal stress in Murrah buffaloes as evidenced by significantly reduced milk production. Hence, additional feed, shelter and management practices might be adopted to overcome the negative effects of thermal stress and also to optimize milk production of the animals.

\section{Introduction}

Buffaloes contribute significantly to Indian GDP with $49 \%$ of total milk in India. Although buffaloes have not been considered as seasonal breeders but they do show seasonality in breeding and calving, which reduced milk production ultimately in summer
(Himadri, 2007). Milk production is affected by a number of factors like genetic potentiality, age, number of previous lactations, pregnancy, season of calving, calving interval and nutrition status (Bernabucci et al., 2002). Among all the factors, the season of calving is said to have marked effect on total production (Pawar et 
al., 2012). The increase in environmental temperature decreases the milk production during summer. High heat load in lactating buffaloes reduced milk production and has shortened duration of lactation periods (Upadhyay et al., 2007). Heat load and intensity of heat stress can be measured by simple indices such as THI.

Temperature is not the only factor of environment that profoundly affects the intensity of heat stress (Nilufar, 2015). The temperature humidity index (THI) measures the combined effects of ambient temperature (AT) and relative humidity $(\mathrm{RH})$ to ascertain the intensity of heat load. The THI is the best, simplest and most practical index to measure the level of heat stress in dairy cattle (Grewal et al., 2019). THI not only measures heat stress but also determines the impact of heat stress on animal productivity. THI is negatively correlated with milk production and reproduction traits in animals. Milk production was not affected when THI values are between 35 and 72, while a rise in THI from 72 to 76 resulted in sharp decline in milk production (Johnson, 1963). The information pertaining to the effect of climate change on milk production of Murrah buffaloes is scanty. Hence in the present study, the milk production of the animals has been taken into account to find the effect of environmental stress during different seasons.

\section{Materials and Methods}

Eight Murrah buffaloes in advanced pregnancy near to parturition of four to six years of age were randomly selected from Livestock Farm Complex, NTR College of Veterinary Science and a local farm in Gannavaram. The animals were kept in shed with appropriate facilities for feeding and watering. The animals were fed as per ICAR feeding standards (Ranjhan, 1998) with concentrates and roughage stall fed.

\section{Meteorological data}

The experiment was conducted at different days in the month of April -June (summer) and November-January (winter). The meteorological data was recorded daily throughout the experimental period. Temperature humidity index (THI) was calculated using the equation, $\mathrm{THI}=(0.8 \mathrm{X}$ $\left.\mathrm{T}_{\mathrm{db}}\right)+\left[(\mathrm{RH} / 100) X \mathrm{~T}_{\mathrm{db}}-14.4\right]+46.4\left(\mathrm{~T}_{\mathrm{db}}=\right.$ temperature of dry bulb, $\mathrm{RH}=$ relative humidity) (Mader et al., 2006) from daily recordings of AT and $\mathrm{RH}$.

$\mathrm{THI}=0.72\left(\mathrm{~T}_{\mathrm{db}}+\mathrm{T}_{\mathrm{wb}}\right)+40.6$

Where, $\mathrm{T}_{\mathrm{db}}=$ dry bulb temperature $\left({ }^{\circ} \mathrm{C}\right) \mathrm{T}_{\mathrm{wb}}=$ wet bulb temperature $\left({ }^{\circ} \mathrm{C}\right)$

\section{Milk Production}

The buffaloes were hand milked daily and the milk production was recorded both in the morning and evening from day of parturition to three weeks post calving.

\section{Statistical analysis}

The average mean values of the two groups were compared using unpaired t-test (Snedecor and Cochran, 1994). The whole data was analyzed using computerized software programme SPSS Ver.20.0.

\section{Results and Discussion}

The mean of milk production in both the seasons studied has been mentioned in Table 1. The mean of meteorological parameters, for the seasons studied has been mentioned in the Table 2 and 3. Significant difference $(p<0.05)$ was evident in minimum, maximum and mean THI of both the seasons.

The present study recorded significantly higher milk production (L/day) during winter $(\mathrm{p}<0.05) \quad(6.77 \pm 0.44)$ compared to summer 
(4.66 \pm 0.15$)$ season as evidenced in Table 1. The present findings were consistent with the earlier results reported by Catillo et al., (2002); Ahmad and Shafiq (2002); Afzal et al., (2007); Upadhyay et al., (2007) and Pawar et al., (2012) in buffaloes. Parallel to the present findings decreased milk production during summer was also reported in cattle by Bajwa et al., (2004) and Akcay et al., (2007).

Decline in milk yield as a direct result of high environmental temperatures was evidenced by Marai et al., (2009). Lactating buffaloes under heat stress have increased reliance on glucose as a fuel source. Heat-stressed buffaloes seem to change their metabolism to preserve glucose for extra-mammary tissues, at the expense of milk lactose synthesis. Despite having a much greater energy content, oxidizing fatty acids generates more metabolic heat ( $2 \mathrm{kcal} / \mathrm{g}$ or $13 \%$ on an energetic basis) compared to glucose. Heat stressed animal become hypersensitive to insulin, and will reduce or block adipose mobilisation and increase glucose 'burning' in an attempt to minimise metabolic heat production. This diverts glucose from mammary tissue to other body tissues and reduces glucose supply to the mammary gland for lactose production leading to reduced milk yield. This may be the primary mechanism for reduction in milk yield during summer (Baumgard et al., 2006).

Table.1 Showing comparison of milk production in different seasons under study

\begin{tabular}{|c|c|c|}
\hline Parameters & Season & Mean \\
\hline $\begin{array}{c}\text { Milk Production } \\
\text { (L/day) }\end{array}$ & Summer & $\mathbf{4 . 6 6}^{\mathbf{B}} \pm \mathbf{0 . 1 5}$ \\
\cline { 2 - 3 } & Winter & $\mathbf{6 . 7 7}^{\mathbf{A}} \pm \mathbf{0 . 4 4}$ \\
\hline
\end{tabular}

Table.2 Comparison of THI in different seasons under study

\begin{tabular}{|c|c|c|c|c|}
\hline Parameters & Season & Minimum & Maximum & Mean \\
\hline THI & Summer & $66.63^{\mathrm{Ab}} \pm 1.79$ & $93.05^{\mathrm{Aa}} \pm 0.98$ & $\mathbf{8 0 . 3 8}_{ \pm \mathbf{A}} \mathbf{A}_{\mathbf{1 1}}$ \\
\cline { 2 - 5 } & Winter & $\mathbf{5 9 . 2 1}^{\mathbf{B b}} \mathbf{\pm 1 . 9 5}$ & $\mathbf{8 3 . 0 6}^{\mathbf{A a}} \mathbf{a}_{ \pm \mathbf{2 . 0 8}}$ & $\mathbf{7 1 . 0 3}_{ \pm} \mathbf{B}_{\mathbf{1 . 1 7}}$ \\
\hline
\end{tabular}

Table.3 Depicting the mean of Meteorological parameters recorded during the seasons studied Summer (April -June) and Winter (November -January)

\begin{tabular}{|c|c|c|c|c|c|c|c|c|}
\hline Season & MONTH & $\begin{array}{c}\text { Tmax } \\
\mathbf{0} \\
(\mathbf{C})\end{array}$ & $\begin{array}{c}\text { Tmin } \\
0 \\
(\mathrm{C})\end{array}$ & $\begin{array}{c}\text { RHm } \\
\mathbf{a x} \\
(\%)\end{array}$ & $\begin{array}{c}\text { RHmi } \\
\text { n } \\
(\%)\end{array}$ & THImax & THImin & Mean THI \\
\hline \multirow{3}{*}{$\begin{array}{c}\text { Summer (April } \\
\text {-June) }\end{array}$} & April, 2019 & 38.91 & 26.03 & 74.43 & 46.00 & 92.07 & 64.83 & 78.45 \\
\hline & May, 2019 & 41.26 & 28.35 & 70.7 & 48.49 & 94.03 & 68.41 & 81.22 \\
\hline & June, 2019 & 39.48 & 28.8 & 65.2 & 51.30 & 89.25 & 69.74 & 79.500 \\
\hline \multirow{4}{*}{$\begin{array}{c}\text { Winter } \\
\text { (November - } \\
\text { January) }\end{array}$} & & 39.88 & 27.72 & 70.11 & 48.60 & $93 \pm 0.98$ & $66.6 \pm 1.7$ & $80.3 \pm 1.1$ \\
\hline & $\begin{array}{c}\text { November, } \\
2018\end{array}$ & 35.47 & 24.1 & 82.2 & 54.43 & 85.14 & 61.15 & 73.14 \\
\hline & December, 2018 & 32.49 & 21.17 & 83.5 & 57.39 & 80.98 & 57.25 & 69.11 \\
\hline & January, 2019 & 29.41 & 18.46 & 86.54 & 56.54 & 89.36 & 64.48 & 76.97 \\
\hline & & 32.45 & 21.24 & 84.08 & 56.12 & $83 \pm 2.0$ & $59.2 \pm 1.9$ & $71 \pm 1.1$ \\
\hline
\end{tabular}


The effect of environment on the health and productivity of the animals is well evidenced in different species of animals. The mean THI in the present study was recorded $>80$ units that significantly affected the milk production. Hence, necessary microclimatic alterations are necessary to mitigate effects of the higher THI for optimum production and reproduction in buffaloes. Hence, nutritional and summer managemental strategies need to be adopted to ameliorate additive effects of summer stress during transition period for optimum production and well being of dairy buffaloes.

\section{Acknowledgements}

This work was done as part of Ph.D. programme. The authors are greatly thankful to Sri Venkateswara Veterinary University. We thankfully recognize the accessibility of the necessary facilities provided by NTR College of Veterinary Sciences, Gannavaram, is duly acknowledged.

\section{Conflict of Interest}

The authors declare that there is no any conflict of interest for this manuscript.

\section{References}

Afzal, M., Anwar, M., and Mirza, M. A. 2007. Some factors affecting milk yield and lactation length In Nili Ravi buffaloes. Pakistan Veterinary Journal 27(3): 113.

Ahmad, M., and Shafiq. M. 2002. Effect of season on fertility rate and milk production in Nili Ravi buffaloes. $23^{\text {rd }}{ }^{\text {Annual Report, Livestock }}$ Production Research Institute, Bahadurnagar, Okara, Pakistan.

Akcay, H., Ilaslan, M., Koc, A. 2007. Effects of calving season on milk yield of holstein cows raised at Dalaman state farm in Turkey. Adnan Menderes
Universitesi. Ziraat Fakultesi Dergisi 4(1-2): 59-61.

Alameen, A. O., and Abdelatif, A. M. 2012. Metabolic and endocrine responses of crossbred dairy cows in relation to pregnancy and season under tropical conditions. American-Eurasian Journal of Agricultural \& Environmental Science 12(8): 1065- 1074.

Al-Saiady, M. Y., Al-Shaikh, M. A., AlMufarrej, S. I., Al-Showeimi, T. A., Mogawer, H. H., and Dirrar, A. 2004. Effect of chelated chromium supplementation on lactation performance and blood parameters of Holstein cows under heat stress. Animal Feed Science and Technology 117(3-4): 223-233.

Bajwa, I. R., Khan, M. S., Khan, M. A., and Gondal, K. Z. 2004. Environmental factors affecting milk yield and lactation length in Sahiwal cattle. Pakistan Veterinary Journal 24(1): 2327.

Baumgard, L. H., Wheelock, B., Shwartz, G., Brien, M. O., Van Baale, M. J., Collier, R. J., Rhoads, M. L., and Rhoads, R. P. 2006. Effects of Heat Stress on Nutritional Requirements of Lactating Dairy Cattle. Proceedings of the $5^{\text {th }}$ Annual Arizona Dairy Production Conference: 8-17.

Bernabucci, U., Ronchi, B., Lacetera, N., and Nardone. A. 2002. Markers of oxidative status in plasma and erythrocytes of transition dairy cows during hot season. Journal of Dairy Science 85(9): 2173-2179.

Broucek, J., Nova, P A V E L., Vokralova, J., Soch, M., Kisac, P., and Uhrincat, M. 2009. Effect of high temperature on milk production of cows from freestall housing with natural ventilation. Slovak Journal of Animal Science 42(4): 167-173. 
Catillo, G., Macciotta, N P P., Carretta, A., and Cappio-Borlino. A. 2002. Effects of age and calving season on lactation curves of milk production traits in Italian water buffaloes. Journal of Dairy Science 85(5): 1298-1306.

Grewal, S., Aggarwal, A., and Alhussien, M. N. 2019. Seasonal alterations in the expression of inflammatory cytokines and cortisol concentrations in periparturient Sahiwal cows. Biological Rhythm Research 1-11. DOI: 10.1080/09291016.2019.1670971.

Himadri, P. 2007. Heat shock protein (s) and lymphocyte response in heat stressed buffaloes Ph.D. Thesis, ICAR-National Dairy Research Institute, Karnal, Haryana.

Johnson, H. D., Ragsdale, A. C., Berry, I. L., and Shanklin, M. D. 1963. Temperature-humidity effects including influence of acclimation in feed and water consumption of Holstein cattle. Univ. of Missouri Res. Bull (846).

Marai, I,, Daader, A., Soliman, A., and ElMenshawy, S. 2009. Non-genetic factors affecting growth and reproduction traits of buffaloes under dry management housing (in subtropical environment) in Egypt.
Livestock Research and Rural Development 4(4): 6.

Nilufar, H. 2015. Studies on seasonal stress induced changes on plasma hormones, metabolites and milk plasminogenplasmin system in Murrah buffaloes. Ph.D. Thesis, ICAR-National Dairy Research Institute, Karnal, Haryana.

Pawar, H. N., Kumar, G. R., and Narang, R. 2012. Effect of year, season and parity on milk production traits in Murrah buffaloes. Journal of Buffalo Science 1(1): 122-125.

Ranjhan, S.K. Editor. Nutrient Requirements of Livestock and Poultry. New Delhi: Indian Council of Agriculture Research, 1998.

Snedecor, G.W., and Cochran, W.G. 1967. Statistical Methods. Iowa State University Press, Ames, Iowa. 196:4451.

Upadhyay, R.C., Singh, S. V., Kumar, A., Gupta, S. K., and Ashutosh. 2007. Impact of climate change on milk production of Murrah buffaloes. Italian Journal of Animal Science 6(2): 13291332.

Upadhyay, R. C., Singh, S. V., Kumar, A., Gupta,S.K., and Ashutosh. 2007. Impact of climate change on milk production of Murrah buffaloes. Italian Journal of Animal Science 6(2): 13291332.

\section{How to cite this article:}

Vasantha, S. K. I., Ch. Srinivasa Prasad, B. Rambabu Naik, K. Aswani Kumar, Ch. Venkata Seshaiah and Nikhil Kumar Tej, J. 2021. Effect of season on milk production in Murrah Buffaloes: THI a proven marker. Int.J.Curr.Microbiol.App.Sci. 10(04): 252-256. doi: https://doi.org/10.20546/ijcmas.2021.1004.025 